\title{
Modernism(s) in Dutch Literature
}

\author{
HUBERT F. VAN DEN BERG AND GILLIS J. DORLEIJN
}

University of Groningen

\section{A Plethora of Modernisms}

"Modernism" is a recurring feature in Dutch literary history. Nowadays, most historical surveys distinguish a "modernism" in the Dutch literature of the past century-and-a-half, either as a school, movement or period. Nevertheless, it should be noted that the distinction of a "modernism" as a more or less neutral descriptive classification is, in fact, a quite recently established practice in the historiography of Dutch literature. Although the term "modernism," Dutch: modernisme, can be found in discussions of Dutch literature (and art) since the early twentieth century, the notion of "modernism" was generally used, however, not as a descriptive, historiographical category, but rather as a pejorative label in the context of critical-polemical assessments. Only in the last decades has "modernism" gradually turned into a by-and-large neutral term in Dutch literary history, mainly as a consequence of two recent developments in the Dutch literary field and, in particular, in Dutch literary studies. The first was the growing internationalisation of Dutch literary studies, which implied a considerable impact of English and American literary historiographical practices on the (local) study of Dutch literature; the second was the emergence of the category "postmodernism" as a popular label in Dutch literary studies and criticism in the 1980s that necessitated the introduction of an - until then virtually absent - "modernism" as movement or period preceding the postmodern present.

As a result, a broad consensus exists nowadays regarding the need to delineate a period called modernism. This agreement seems to vanish, however, when questions have to be answered as to what modernism exactly encompasses, how modernism should be understood, and when and where modernism manifested itself in Dutch literature. A more precise review of the historiography of Dutch literature shows, in fact, a wide variety of "modernisms" which partly overlap and intermingle, yet partly exclude each other as well. To name some: a "classical modernism," "ultramodernism" and "metamodernism" (Vuyk [1999], 78-81]) next to a "non-spectacular modernism" (Sötemann [1976]), a left-wing and a right-wing modernism (Vaessens [1998]), a moderate and a radical modernism (Fontijn and Polak [1986]), "aristomodernism" and "vulgomodernism" (Ruiter and Smulders [1996]) next to "postmodern modernists and modernist postmodernists" (Jaap Goedegebuure [2001]), each with a scope of its own.

Opinions not only differ concerning the content of the concept of modernism, but also in regard to the period in which modernism manifested itself in Dutch literature. Some trace the beginnings of modernism in Dutch literature back to the late nineteenth century (circa 1880 or a decade later, 
cf. Gobbers [1997], Sötemann [1978], Bulhof [1995]). Others situate the first manifestations of modernism somewhere at the start of the twentieth century - in 1909, more or less simultaneous with the publication of the first Futurist manifesto, or rather in 1916, a year considered by many as a fault line in Dutch literature in the Netherlands (see Brandt Corstius [1976], Anbeek [1987]). That year was significant not only because Martinus Nijhoff, a poet and critic who dominated Dutch literature in the twenties and thirties, published his first volume of poetry, De Wandelaar (The Hiker), but also because Theo van Doesburg, editor-to-be of the internationally influential magazine $D e$ Stijl (The Style), founded in 1917, wrote a series of essays on the foundations of constructivist art, "De Nieuwe Beelding in de Schilderkunst" (New Figures in the Art of Painting). Furthermore, a new periodical, Het Getij (The Tide), was launched, offering an important forum for new developments in literature nowadays termed as modernist and avant-garde. Finally, in the same year in Flanders, Paul van Ostaijen published his first collection of poems, Music-Hall.

In other histories, modernism emerges only after World War I as a parallel development next to or as part of the historical avant-garde, sometimes only after the breakdown of the European avantgarde in the late twenties (see Fontijn and Polak [1986], van den Akker [1994]). And, whereas in the historiography of Dutch literature modernism is regarded mostly as a phenomenon of the first half of the twentieth century, one may also find modernism invoked in discussions of developments after World War II. For example, Paul Hadermann describes experimental literature since 1945 as a "second wave" of modernism in Dutch literature, which, in fact, led to the actual breakthrough of modernism in Dutch literature in the 1950s (Hadermann [1988], 273). This experimental literature, involving the work of among others Remco Campert, Gerrit Kouwenaar, Hugo Claus, Sybren Polet and Lucebert, partly in close relation to the Cobra movement and other neo-avant-garde artistic developments, is often described as modernist, in particular in essayistic literary criticism (see Gobbers [1997], 61, and for example Buckinx [1953], Verslag [1963], 2255, Weisgerber [1970], Denoo [1978], Mandelinck [1991], van Montelbaan [1996], Thomas [1961], de Waard [1999]). Even today, this post-1945 modernism is sometimes regarded as the "dominant discourse" in Dutch letters, for instance by the poet Elly de Waard in a recent issue of the literary review De Revisor (De Waard [1999], 4), in which another critic distinguished no less than "four forms of modernism" in the novel Liefdesdood (Death of Love) by Oscar van den Boogaard, which was published the same year (see Vuyk [1999]). A decade earlier, J. A. Dautzenberg drew an even longer line in Nederlandse literatuur-Geschiedenis, bloemlezing en theorie (Dutch Literature -History, Anthology and Theory), in accordance with De Waard's assumption:

Around World War I, a new major period began in cultural history, which we call modernism, and in which we still live. All we nowadays call "modern art" emerged in the first quarter of the 20th century. Contemporary artists still work by the same principles as those around 1915 [...]. (Dautzenberg [1989], 267-8). ${ }^{1}$

These differences in the way modernism is situated chronologically coincide self-evidently with differences in the characterization of subsequent modernisms. Some relate their concept of modernism to the extent that writers, groups, movements or schools took notice of "modern" society and reflected on modernity in all (or some of) its aspects. Factors like industrialisation, rationalization, secularization, and the social and political emancipation of the masses - in short, elements of Max Weber's Entzauberung der Welt (Disenchantment of the World) - are, then, major constitu- 
ents of the context of a modernism situated temporally in the last decades of the nineteenth century. A second conglomerate of concepts understands modernism more or less as an umbrella term for the many isms of the so-called historical avant-garde (in the Netherlands by and large: during and after the Great War), including all forms of expressionism. Whereas the first modernism comprises a variety of cultural developments in the fin de siècle, this second modernism was, actually, directed against the culture of the fin de siècle. And, finally, a third concept can be made out in which modernism, in turn, opposed the historical avant-garde. This modernism manifested itself more or less in the same period as the avant-garde, yet flourished in particular ("high modernism") in the late 1920s and $1930 \mathrm{~s}$, after the gradual dissolution of the historical avant-garde movements.

Besides, considerable differences can be made out in the way these three modernisms are distinguished and characterized. Some focus on the historical context and regard the literature of modernism as a reaction to the "modern" world, in which the changing role of literature as well as changes in the production and consumption of literature are of relevance. Another perspective focuses rather on conceptions of literature by respective authors: the question whether a literary text, a writer, group, or school should be labeled modernist, is primarily related to the opinions of authors and critics presented in essays, manifestos, critiques or other writings. Yet another approach focuses mainly on the literary products as texts, in which "modernist" traits can be discerned, both in content and in form.

Apart from all the differences there are, however, also some remarkable correspondences in the way certain parameters are used to distinguish different modernisms. Be it the literary reflection on modern life or modernity, be it the intention, embedded in specific conceptions of literature, to create an autonomous work of art, or be it epistemological doubt and linguistic skepsis as a constitutive factor for the presence of modernism: all these criteria can and are used not only for the distinction of modernism in a broad sense, but also for the distinction of the other, more restrictive, rivaling notions of modernism. Obviously, these three approaches have a tendency to intermingle and overlap (as for example in Fontijn and Polak [1986] and Vaessens [1998], see also Beekman [1985] and Grüttemeier [1995]).

\section{Three Modernisms in Current Dutch Literary Historiography}

\section{Modernism as literature of modernity}

The three umbrella concepts of modernism circulating in Dutch literary historiography comprise two rather narrow and one broad notion of modernism. In the last case, modernism points - as Walter Gobbers argues ([1997], 54) — at the whole complex of radically innovative movements in the art and literature of the second half of the nineteenth and the first quarter of the twentieth century in the context of (and reacting to) modern, capitalist industrialized society and culture (in short: modernity), which lead to a fundamental and definitive abandonment of hitherto dominant classicist artistic codes. This modernism encompassed a wide variety of writers, schools, and movements. As a result, this modernism in a broad sense is both diachronically and synchronically a quite heterogeneous, sometimes in itself contradictory phenomenon, including not only naturalism, symbolism, decadent literature, impressionism, and Art Nouveau, but also the historical avant-garde movements in all their multiformity (Gobbers [1997], 54-5). 
This broad notion of modernism, obviously kindred to the concept of modernism at the base of Modernism by Bradbury and McFarlane (1976) as well as Modernisms by Peter Nicholls (1995), implies for the historiography of Dutch literature of the past two centuries that a wide variety of divergent literary developments can be described as different forms of one single modernism. Starting with the so-called Movement of Eighty in the 1880s in the Netherlands and with the review Van Nu en Straks (Of Now and Later) in the 1890s in Flanders (both with an international focus on French naturalism, English aestheticism and, in the Flemish case, on the Arts and Crafts movement as well as on Jugendstil, and Art Nouveau), they include the later literary experiments in the literary and artistic circles around Paul van Ostaijen in Flanders and Theo van Doesburg and De Stijl in the Netherlands as well, and have the poetry of the Dutch author Hendrik Marsman at their tail end.

At a symposium in Oldenburg in 1995, Francis Bulhof ([1995], 238) justly pointed out that "Anyone only slightly informed about Dutch literature will be amazed about its absence in Bradbury [and McFarlane]."2 Bulhof, however, is not completely right when he continues: "Van Nu en Straks, the review that represented the feeling of modern life in Belgium, isn't even mentioned," since of all manifestations of Dutch literary modernism, Bradbury and McFarlane ([1991], 203) do in fact mention only Van $\mathrm{Nu}$ en Straks. Bradbury and McFarlane ignore, however, the Dutch Movement of Eighty and the review De nieuwe gids (The New Guide), in which — in the Netherlands - naturalism found a certain response and a new expressive notion of literature was developed against a traditional rhetorical poetics dominated by church(es) and state. In this movement, Herman Gorter, Lodewijk van Deyssel and J. H. Leopold were engaged in literary experiments, on the one hand embracing the special attention for the subtleties of emotions and expressive possibilities that can be found in the fin de siècle and in symbolism, on the other hand anticipating the explorations of the margins of language in the following historical avant-garde. Yet, these are not the only major developments around the previous turn of the century that are ignored in the volume edited by Bradbury and McFarlane. Their Modernism also leaves unmentioned literary contributions to the so-called "historical avant-garde" in the Netherlands and Flanders in the late 1910s and early 1920s. Modernism ignores not only Dutch poets influenced by expressionism like Herman van den Bergh, Hendrik Marsman and Hendrik de Vries, but also the substantial contributions to expressionist and constructivist experimental poetry by Paul van Ostaijen and Theo van Doesburg (I. K. Bonset). Van Ostaijen and Van Doesburg were not only pivotal figures in the Flemish and Dutch literary avant-garde; in particular Van Doesburg (Bonset) also played a profound role in the European avant-garde on an international level in the context of dada and constructivism.

Since most, if not all Dutch literature between the late nineteenth century and the mid-1920s can be summarized as modernism using the wide definition by Gobbers or Bradbury and McFarlane, the differentiating capacity of the term is, as a consequence rather small, not least due to the heterogeneous character attributed to modernism. There may be some Dutch authors, in particular in the orthodox Calvinist and Catholic strata of the literary field, who cannot be qualified as "modernists," due to their overt traditionalism. Most of those involved in literary activities and in some way "up to date," however, could be described as "modernists." As a critical term, modernism may, therefore, not possess the capacity to differentiate within Dutch literature; however, it does facilitate the description of continuities, in particular since the wide scope of the term leaves room for contradictions and controversies as well as for "internal" modernist innovation. Though a claim to radic-

(C) 2007. John Benjamins Publishing Company

All rights reserved 
al unprecedented innovation can be found especially in the historical avant-garde - a claim often repeated in the historiography of this avant-garde - a more precise examination of avant-garde conceptions and poetics, for example by Van Doesburg or Van Ostaijen, shows an apparent historical continuity as well as lines of tradition, which often led to the modernisation of Dutch literature in the late nineteenth century, despite the quite fierce polemics by the Dutch avant-garde against their fin de siècle forerunners (see van den Berg and Dorleijn [2002]). In the Netherlands, for example, the Movement of Eighty had broken radically with the rhetorical Calvinist clergyman's culture and a moralist literary practice that dominated Dutch literature in the nineteenth century and had proclaimed the opening of Dutch literature towards a new, modern poetics with much enthusiasm. This movement had such an impact on literary life in the Netherlands that it could occupy the niche of the modern for a long time. All writers until World War II recognized that Eighty meant the start of modern Dutch literature, even if they criticized the movement for one reason or another (cf. van den Akker and Dorleijn [2000]).

The main relevance of the wider notion of modernism, which can be found in particular - and certainly not accidentally — on those occasions when Dutch literature is presented in a wider, international setting, seems to accord with the possibility of placing Dutch literature in an international framework of modernism and to present the Dutch contribution(s) to this international modernism, to paraphrase the subtitle of several English publications on Dutch modernism. This effort, however, has met with very limited success. In 1995, in his Oldenburg paper on the debate on modernism in Dutch literary studies, Bulhof complained, as mentioned, about the absence of the Movement of Eighty and Van Nu en Straks in Modernism by Bradbury and McFarlane. Bulhof concluded that Dutch modernism remained still by and large unnoticed outside the Low Countries:

This most radical modernist revolution in the European literature of the fin de siècle isn't mentioned at all by Bradbury [and McFarlane]. Once more, the chance to integrate Dutch literature in the wider European context has not been utilised. This first modernist wave was followed around World War I by a second, in which avant-garde movements like imagism, futurism, expressionism, dadaism, and surrealism dominated. But here too, the Dutch input in the international debate in literary studies is minimal, although Dutch and Belgian contributions can be found in abundance. (Bulhof [1995], 239) ${ }^{4}$

An indication for the unsuccessful integration of these Dutch modernist revolutions - to use Bulhof's qualification - in the historiography of European modernism in a broad sense, despite a considerable number of studies on Dutch literary modernism in English since the first publication of Bradbury and McFarlane's book now twenty-five years ago, could be the fact that even the one and only reference to Dutch literary modernism in their Modernism was eliminated in 1995 by Peter Nicholls in his Modernisms.

\section{Modernism, or (traces of) the historical avant-garde}

Whereas the previously discussed notion of modernism functions as an umbrella term for a larger period in which modern literature manifests itself in all its variety of divergent authors, schools, and movements, competing with, opposing, complementing, substituting, or superseding each other, the term "modernism" is used by others in a more restricted way (a practice criticised by proponents of the wider understanding of modernism, like Gobbers [1997], 60-1). In the historiography of Dutch literature, notably two other more narrow conceptions of modernism can be found. 
In Dutch literary as well as art history, "modernism" serves frequently as an (alternative) denomination for the multiform, yet still far more homogeneous conglomerate of isms also subsumed under the label "historical avant-garde". In line with the classification introduced by Peter Bürger (1974) and nowadays common in German historiography, several literary historians refer to this conglomerate of radically innovative movements in the arts in the first decades of the twentieth century - including notably futurism, cubism, and to some extent expressionism in the years before World War I, dada during the war, and surrealism and constructivism in the following years — as "historical avant-garde", also in the context of Dutch and Belgian literary history (see Drijkoningen [1982], Weisgerber [1984] and [1991]). Others, though, tend to refer to the same developments in the context of Dutch and Belgian art and literature as "modernism" (cf. Bulhof [1976], Fontijn and Polak [1986], Hadermann [1988], Chamuleau and Dautzenberg [1991], Dautzenberg [1989] as well as: Blotkamp [1989], Bruinsma [1998], Buelens [1996], [1997] and [2000], de Jong [1979], [1982a] and [1982b], Musschoot [1979], van der Ploeg [2000], de Vree [1977] and Fokkema and Ibsch [1984], 23).

When "modernism" serves as a synonym for "historical avant-garde," some minor differences in their application can still be observed. "Historical avant-garde" is used in particular as a denomination for the movements and groups involved (thereby pointing at the social dimension of the avant-garde). "Modernism," on the other hand, serves not only as a common denominator for the aesthetic expressions of these movements and groups, but also for kindred, yet frequently less radical innovative art and literature by other artists and authors who themselves were not or only marginally involved in the avant-garde as a social network. The term "historical avant-garde" in this understanding of "modernism" often refers to the hard core of "modernism" in the 1910s and 1920s or - as Jan Fontijn and Inge Polak $(1986,182)$ put it: modernism may have been innovative and experimental, but never broke fully with literary traditions, unlike the avant-garde. In line with this difference, Fontijn and Polak ([1986], 183) distinguish two versions of modernism, a radical version (the historical avant-garde), including futurism, dadaism, constructivism, and surrealism on the one hand, and a moderate modernism, including expressionism and the Nieuwe Zakelijkheid (New Objectivity) on the other.

In this way, "modernism" offers a solution for a double historiographical problem. Firstly, several Dutch authors may have sympathized with foreign avant-garde developments and even experimented in an avant-garde way themselves. It is noteworthy, however, that even those practitioners in the Dutch literary field who had obvious avant-garde sympathies on an aesthetic or poetical level, never showed the ambition to present themselves as avant-garde or to create a new avant-garde movement, with one exception: the circle around the constructivist review De Stijl. But this circle was represented only marginally in the Dutch literary field. Most of its members were visual artists, architects, and designers. Some of them ventured into the literary field with work of their own, next to their core visual oeuvre (notably Theo van Doesburg and Piet Mondrian). Other writers in the informal Stijl circle were amateur poets (Agnita Feis, Evert Rinsema, and Antony Kok) with no stronghold in the literary field.

Next to De Stijl other, mostly young authors joined in with innovative developments represented elsewhere by avant-garde movements: Hendrik Marsman, Herman van den Bergh, Hendrik de Vries, Constant van Wessem, the early E. du Perron (Duco Perkens), Albert Carel Willink and Hendrik Nicolaas Werkman (the latter two as visual artists as well). These authors generally did

(C) 2007. John Benjamins Publishing Company

All rights reserved 
not operate as representatives of a (foreign) movement, but rather on their own. Whereas Marsman, Van den Bergh, and De Vries followed certain trends in German expressionism in their early work, they did not present themselves as Dutch representatives of (German) expressionism or as representatives of a Dutch expressionism, but rather as Marsman, Van den Bergh, and De Vries. The same holds true for Du Perron, Willink, and Werkman. In the (early) 1920s, Willink and Werkman took part in avant-garde developments which may be termed "constructivist". Besides, Willink and $\mathrm{Du}$ Perron played a modest role in an avant-garde network with expressionist tendencies as well as a constructivist focus. This network included among others the Antwerp review Het Overzicht (The Survey), Der Sturm (The Storm) from Berlin and the Romanian journal Contimperanul as well as — in the margins - the little review De Driehoek (The Triangle in 1925), edited by Du Perron together with Paul van Ostaijen and Gaston Burssens. As far as they aimed at a position in the Dutch literary field, however, none of the authors involved presented themselves as representatives of the avant-garde, or of for instance constructivism. Only Paul van Ostaijen was an exception, insofar as he related his work explicitly to expressionism and cubism. He too was cautious, though, to specify his "own" expressionism and cubism by idiosyncratic qualifications. Thus, he typified his poetics in 1920 in "Et voilà. Een inleidend manifest" as geëmansipeerd kubisme - emancipated cubism (Van Ostaijen [1979b], 129-34, 129), and firmly opposed a "humanitarian" or "romantic" expressionism in favor of an expressionist brand of his own: so-called "organic expressionism," meaning a form of literary constructivism working on the basis of pure poetry, yet with some clear-cut mystical features (Van Ostaijen [1979b], 378, 328-30, 264-81, 270):

[O]rganic-expressionist poetry and art aim at a formal a-seity, at a construction balancing parts against each other which are in themselves already complete. [...] Ultimately, organic-expressionist atmosphere equals this vibration between two isolated groups [of objects or words]. [...] Before I say the word, there is a yearning for expression of the unknown [...]. Time and again the expression is altered by its own surprises. [...] The painting comes into existence on the canvas; the genesis of a poem determines its own content. (Van Ostaijen [1979b], 277-8)

Van Ostaijen's later, constructivist poems are, in a way, little linguistic machines in which musical structures prevail. Typographical design plays an essential role and self-referential elements emerge, as "Zeer kleine speeldoos" (Very Tiny Music Box) demonstrates (Van Ostaijen [1979a], 209):

\author{
VERY TINY MUSIC BOX \\ Amaryllis \\ here is \\ Iris \\ in a soapbubble
}

hang the bubble

on a ring

and the ring

on your nose

Amaryllis

(C) 2007. John Benjamins Publishing Company

All rights reserved 
Shake your head

and the light

plays with Iris

in the bubble

Shake it hard

the bubble breaks

Amaryllis

\author{
Where is \\ Iris \\ Iris was here \\ Amaryllis \\ on a ring \\ and the ring \\ on your nose
}

\title{
Snooty nose
}

Amaryllis ${ }^{6}$

In the second place, several authors in the early-twentieth-century Dutch and Flemish literary field may have taken up innovations which were developed and represented by foreign avant-garde movements. But in most cases they did so with some retardation. There may have been avant-gardism in early-twentieth-century Dutch literature, yet mostly it followed foreign developments - understandably with some delay. Exceptions, again, are the contributions to constructivism by De Stijl and Paul van Ostaijen, with his volume of poetry Bezette stad (Occupied Town, 1920). The case of expressionism is typical, however. Whereas expressionism in Germany was already waning in the late 1910s, it was only then that the first influences of this expressionism became noticeable in Dutch literature, e.g. in the work of Herman van den Bergh and Hendrik Marsman. In Flanders, (German) expressionism may have had some impact a few years earlier, for example in the early poetry of Van Ostaijen (notably in his poetry collections, Music-Hall of 1916 and Het Sienjaal (The Sign) of 1918). But it is typical in the case of Van Ostaijen as well, that he still presented himself explicitly as an expressionist, be it as an "organic expressionist", at a stage, in the 1920s, when expressionism in Germany had already become yesterday's fashion.

Foreign avant-garde developments were generally appropriated with some delay, and often in a weakened form. The avant-garde orientation of most Dutch writers was basically confined to moderate forms of expressionism (leaving aside the question here, to what extent expressionism as a whole can be regarded as avant-garde development). The poetry by Hendrik Marsman in the series "Seinen" (Signals), written around 1920, which was inspired by the experimental work of the Sturm poet August Stramm, is the only exception, at least in Dutch literature from the Netherlands. The situation in Flanders may be slightly different, in particular in the case of Paul van Ostaijen who during a longer stay in Berlin in 1918-20 authored his already mentioned Bezette Stad, a poetry volume full of "rhythmic typography," compatible with the poetical experiments of Apollinaire and the dadaists. Yet, also in the case of Van Ostaijen an obvious change can be noticed after his 
return to Antwerp in 1921, when radical experiments in his work are reduced in favour of a more conventional poetics. Typical is Van Ostaijen's double entry in a recent history of Dutch literature, Nederlandse Literatuur, een geschiedenis (Dutch Literature, a History, 1993). In this history, Paul van Ostaijen makes his first appearance as an avant-garde representative, being considered for the "breakthrough of the avant-garde in Flanders" in October 1918 (Hadermann [1993a], 602-9). Later on, Van Ostaijen is introduced once more, now as member of "a modernist triumvirate" together with Burssens and Du Perron as co-founders of De Driehoek in 1925 (Hadermann [1993b], 621-9, cf. also Buelens [1997]).

The gradual difference between "modernism" and "historical avant-garde" offers — in summary - a solution for the problem that some avant-gardism can be found in early twentieth-century Dutch literature, yet mostly in a moderate form and sometimes - at least from an international perspective - with a slightly epigonal character. Whereas the criteria for a historiographical recognition as historical avant-garde are quite strict (cf. Drijkoningen [1982]), "modernism" leaves some more room for maneuvering, allowing even the description of decisively non-avant-garde innovation in Dutch letters as "moderate modernism," as in the case of Martinus Nijhoff.

Nijhoff created a singular oeuvre, which cannot be attributed unambiguously to one school or movement. Additionally, Nijhoff combined innovation with traditional forms. A.L. Sötemann was the first to characterize Nijhoff as a moderate modernist in two lectures in 1973 and 1976, entitled “ 'Non-spectacular' Modernism: Martinus Nijhoff's Poetry in its European Context” (published 1976) and "Some suggestions concerning two modernist traditions in European poetry" (published 1977). Sötemann didn't place Nijhoff in the more narrow framework of modernism as historical avant-garde, but rather in the previously described wider notion of modernism, for which Hugo Friedrich's Die Struktur der modernen Poesie (The Structure of Modern Poetry) served as a guideline. As Sötemann argues, Nijhoff took an autonomist, anti-expressive and anti-mimetic position in his conception of literature, and should therefore be regarded as a representative of a "modern" tradition of pure poetry. Sötemann points out that Nijhoff's work was related to many different "modern" schools and movements in the preceding years:

\footnotetext{
I do not know any other poet whose work has been identified with so many different and contradictory schools or movements. If we exclude naturalism, futurism and dadaism, it is hardly possible to think of a term of literary categorization which has not been applied to this poet. He has been called a classical artist as well as a baroque one, a romantic of course, but also a romantic realist. We find his typically parnassien character elaborated upon, but other critics consider him a specifically symbolist poet. Yet others set him down as an aesthete, a decadent, an expressionist, a realist, a cubist, a surrealist, a magic realist or a representative of the Neue Sachlichkeit ("New Objectivity"). (Sötemann [1976], 97)
}

Since Nijhoff's oeuvre can indeed be related to most of these schools and movements, as his work includes different elements of their divergent poetics, one could consider him a modernist par excellence as he combined a wide range of modernist isms; yet he was not a radical modernist, but someone who avoided the extremities and particularities of these schools and movements and aimed at such a "moderate" middle course as a "non-spectacular" champion of modernism:

[...] there seems to be hardly any doubt that Nijhoff started from a complex of presuppositions and assumptions that should be termed typically modern, and that he consistently worked out his individual solution to the resulting problems. In the process he obviously concentrated increasingly on the essen-

(C) 2007. John Benjamins Publishing Company

All rights reserved 
tial principles of modernism, while rejecting a number of facile, strained extremist developments of isolated aspects that had resulted in a number of ostensibly separate movements. Nijhoff's solution is to a large extent unique in a European context. (Sötemann [1976], 116)

Although many other historians point to the special role and place of Nijhoff in early twentiethcentury Dutch literature as well, Sötemann's qualification "moderate modernist" has a different purport. Sötemann describes and positions Nijhoff — in terms of Wiljan van den Akker (1996) — as a "master of modernism". The assumption of a "moderate" version of modernism serves other historians, instead, as a way of situating Nijhoff as a rather idiosyncratic, unique case on the fringes, but still in the conglomerate of movements, groups, and individuals elsewhere described as avant-garde (see for example Fontijn and Polak [1996], 203-5).

\section{International modernism versus historical avant-garde}

It is important to note that the term modernism serves not only as a vaguer synonym for "historical avant-garde", but also as a denomination for a chronologically parallel, yet poetically and aesthetically alternative development in literature from the Netherlands in the 1920s and 1930s opposing the avant-garde. Authors like Nijhoff, who are described by some as moderate, "weak" representatives of a modernism that centers around the hard core of the historical avant-garde (in the 1920s), are regarded by other historians as the main Dutch contributors to an international modernism (in the 1920s and 1930s), which isn't seen as a spin-off of the avant-garde, but is rather defined as an independent, autonomous development in literary life between the two world wars, notably as simultaneous with and after the avant-garde. This third version of modernism in Dutch literary historiography is often discerned in the work of the already mentioned poet and critic Nijhoff who rejected radical avant-gardism in favor of a refined "neo-classical" experiment à la Stravinsky (see Bronzwaer [1988] and [1991]). Nijhoff articulated a literary line of thought that has obvious affinities with the conceptions of T.S. Eliot and Paul Valéry. As with Valéry, he saw the creative process as paramount: the content being one of the effects of formal, linguistic operations. His aim was to produce an autonomous poem in which personal aspects had been erased (see Eliot's "objective correlative"). Nijhoff's poetry abounded with two major themes of modernist literature: reflection on the relation between subject and reality as well as reflection on literature itself (Bronzwaer 1991, 111). As such, Nijhoff can be considered a protagonist of international modernism seen as a specific literary school in the early twentieth century.

As Wiljan van den Akker has pointed out in a discussion of Nijhoff's narrative poem "Awater" (1934) — at least partially a polemical answer to T. S. Eliot's Waste Land - a whole range of modernist features, such as the fundamental estrangement of man in the modern world, the discontinuity of time and history and the impossibility of removing the rift between the present and the past (see Richard Quinones [1985]), the ambiguity and ambivalence of meaning, the use of fragmentary structure, the reflection on the act of writing, as well as intellectual and epistemological skepsis (Van den Akker [1994], 30-1, 44-6), indicate that Nijhoff can be regarded as one of the major representatives, if not the Dutch representative of modernism and not as the traditionalist odd man out of the historical avant-garde. Van den Akker's characterization of Nijhoff as modernist follows Sötemann's positioning of Nijhoff, yet in a more restrictive understanding of modernism compatible with the "modernism" common in the historiography of English litera- 
ture, for example in The Short Oxford History of English Literature (Sanders [1996], 505-76).

The Dutch magazine De Witte Mier (The White Ant, 1924-1926) could be regarded as a local platform for this international modernism represented among others by Nijhoff. It exuded a cosmopolitan atmosphere and showed a profound knowledge of the international artistic situation with references to the work of "modernists" like Valéry, Svevo, Joyce and Eliot. Its publisher, A. A. M. Stols, was very much involved in this international network, being the depositary of the international modernist magazine Commerce (1924-1932), and the publisher of work by Larbaud, Valéry, Rilke and many Dutch authors like Nijhoff, Ter Braak and Du Perron (Levie [1988]).

In particular Menno ter Braak and E. du Perron figure prominently in the monograph Het modernisme in de Europese letterkunde (Modernism in European Literature) by Douwe Fokkema and Elrud Ibsch (1984), of which in 1987 also a slightly revised version was published in English under the title Modernist Conjectures in European Literature 1910-1940. Their prime focus is neither Nijhoff's poetry, nor the magazine De Witte Mier, but rather the narrative and critical prose of a number of Dutch writers who found their momentum in the 1930s (although two of them started to publish already in the twenties) in the context of the influential Dutch literary review Forum (19311935). They include the editors of Forum: the above-mentioned Ter Braak, mainly an essayist with Nietzscheian overtones, and the later Du Perron. Du Perron was an author with a strong international orientation and many foreign contacts, who could count André Malraux among his friends and knew French modernists such as Valéry Larbaud and André Gide. As a firm opponent of the avantgarde after a brief flirtation with Parisian Bohemia in the early 1920s he wrote "neo-classicist" poetry and a large novel, Het land van herkomst (The Land of Origin, 1935), full of intellectual reflections and epistemological misgivings, as well as a very personal form of internationally oriented literary criticism. Also included is the Forum collaborator Simon Vestdijk, an essayist, poet, and prolific novelist, who published among others a notorious novel in the vein of James Joyce's Ulysses as well as a Proustian serial novel. Another writer often mentioned with this group is the novelist and essayist Carry van Bruggen: though not a contributor to the magazine, she was held in high esteem by its editors.

Works by Ter Braak, Du Perron, Vestdijk, and Van Bruggen are described by Fokkema and Ibsch as the actual backbone of the Dutch contribution to a European modernism, which they characterize as a movement opposing the historical avant-garde (cf. Levie [1991], 264-78). Their modernism encompasses authors and works "which do not partake of the historical avant-garde" (Fokkema and Ibsch [1987], 1), presenting a hitherto underestimated alternative to the historical avant-garde of a modest, detached, cautiously rational, self-reflective kind; an intellectualist alternative that remained invisible, since the authors involved failed to manifest themselves as an international movement. Unlike the isms of the historical avant-garde that presented clear-cut, one-sided beliefs in higher values to be forced on humanity, the modernists had, according to Fokkema and Ibsch, only a "provisional, fragmentary" interpretation of the world. Being "sceptics" rather than "enthusiasts," emphasizing "the value of intellectual consideration and reconsideration," they rejected assumedly any form of dogmatism, and instead "propounded their careful hypotheses," presenting "their intellectual hypotheses in arguments which some moments later they may be eager to qualify or even revoke" (Fokkema and Ibsch [1987], 2-4).

It should be noted here, that the authors presented by Fokkema and Ibsch as the most important Dutch representatives of modernism are categorized as "anti-modernists" by other literary histor- 
ians, in particular for their univocal rejection and - in the case of Du Perron - personal rift with the avant-garde (see van der Aa [1994], den Boef [1991], Gillet [1988], 403-5). Ironically, Ter Braak and Du Perron are also known - as editors of Forum - for a critical approach in which the personality of the author and his views serve as the main criterion in the critical apprehension of a work of art, by which they firmly opposed the more formal criticism of "modernists" like Nijhoff as well as of Van Ostaijen's adherents (see Oversteegen [1967]).

It may seem confusing, in the meantime, that Ter Braak and Du Perron have been called "modernists" as well. However, one may also argue that the term "modernism" offers a solution for yet another historiographical problem. If one surveys Dutch literary history between the two world wars and distinguishes a conglomerate of tendencies in the early 1920s that may be labeled "historical avant-garde," a collection of disconnected, individual authors seems to remain in the following period - from the mid-1920s until the German occupation in 1940 - that cannot be classified in a satisfactory way by one ism or another, in particular not by schools and movements commonly distinguished on an international level. In this context it is typical that a chapter on modernism (as historical avant-garde) in a Dutch literary history edited by Van Bork and Laan (1986) is followed by a chapter on the "thirties," discussing a whole range of individual writers and magazines, among others Nijhoff as well as Forum and related authors like Ter Braak, Du Perron, and Van Bruggen. Describing the avant-garde, the umbrella term "modernism" seems to serve Dutch literary history well in several respects, not only as a common denominator for these individual, partly disconnected authors, now regarded as divergent representatives of a counter-tendency opposing the historical avant-garde in Dutch literature in the late 1920s and 1930s, but also as a way to summarize singular Dutch phenomena like Nijhoff's poetry and the poetics of Forum as Dutch contributions to an international development discerned, in particular in English literary studies, in the work of, among others, T. S. Eliot and Virginia Woolf (see Sanders [1996]), who were regarded by the respective Dutch authors as literary peers in many ways.

\section{"Modernism" in the Early Twentieth-Century Dutch Literary Field: A Polemical Invective}

Earlier, we pointed out that the term "modernism" situates literary developments in the Netherlands and Flanders in a wider, international framework. However, if one places the previously distinguished modernisms in Dutch literature in a European, if not global, context, one should be aware of a significant difference between Dutch literature on the one hand, and English and North-American as well as a number of Romanic literatures on the other. In the latter, a positive reinterpretation of the originally pejoratively used terms "modernist" and "modernism" can be observed in the late nineteenth and early twentieth century. Although the terms were simultaneously still used in a negative way, some authors in these literatures started to present themselves (and not their opponents) as modernists (Calinescu [1987], 68-85). In the Dutch as well as Flemish literary field, these terms are used seldom and certainly not as a framework or denomination for oneself. Whereas e.g. Laura Riding and Robert Graves presented themselves in 1927 as advocates and propagandists of modernism in their Survey of Modernist Poetry, in a Dutch context in the same period, "modernism" and "modernist" were used by and large to describe others in a pejorative way. Two exceptions seem to confirm this general rule. In the same year Riding and Graves compiled their survey, H. N. Werk-

(C) 2007. John Benjamins Publishing Company

All rights reserved 
man published an extensive manifesto Land-Volk-Zeit-Kunst written by a fellow artist from Groningen, Johan Dijkstra, on the occasion of an exhibition by the local artist's circle De Ploeg (The Squad). Though written in German, Dijkstra's locally distributed text stated: "BOHEMIAN MENTALITY (SENSE OF FREEDOM), MODERNISM, INTERNATIONALISM, BASIC PROVINCIALISM was the foundation of our thinking [...]" (Dijkstra [1927], 3). ${ }^{7}$ The ironic stance of Dijkstra's remark is obvious. It is also noteworthy that Dijkstra used the term "modernism" in a text written in a foreign language. Two years earlier, the last page of the final issue of the Flemish review Het Overzicht (The Survey) presented a tableau with the names of two dozen congenial avant-garde periodicals. The panorama of predominantly foreign journals had two titles, one in Dutch and one in French. Whereas the French title described the magazines as "Revues modernistes," the Dutch title reads "Tijdschriften," that is simply "reviews" (Anonymous [1925]). In Dutch, the predicate "modernist" was apparently not expedient.

For example in an article in the Italian journal Valori Plastici Theo van Doesburg, editor-in-chief of the constructivist review De Stijl, who regarded himself as a representative of the - then not yet historical - avant-garde that comprised an international front of "all modern and ultra-modern groups" (van Doesburg [1921], 109) stressed that De Stijl was fighting against "modernist dilettantism and snobism" in Dutch art (Van Doesburg, [1920]). ${ }^{8}$ In a compatible way, the later Paul van Ostaijen in the 1920s rejected the shapeless ethical-humanitarian expressionism of several writers of his generation, among others in an essay "Modernistiese dichters" (Modernist Poets), written in 1923 (Van Ostaijen [1979b]: 161-80). In this essay, Van Ostaijen (dis-)qualified the rather pathetic expressionist poet Wies Moens and many other Flemish epigone expressionists as would-be modernists (Van Ostaijen [1979b]: 264-81, 369-79).

The younger writers in the Dutch magazine Het getij (1916-1924), very keen on being "up to date" and innovative (Van Doesburg was even invited as co-editor of the review in 1918), avoided the term "modernism" as well. It was only in 1921 - very late, indeed - that the term "modernism" appeared in the title of a sequence of contributions by "Een dilettant" (a dilettante) presented as a "bloemlezing van modernismen (en archaïsmen)" - a collection of modernisms and archaisms, which contained aphorisms, in part extracted from international avant-garde reviews and manifestos (among others a translation of Tzara's recipe for the creation of a dadaist poem). And even here the term "modernism" was used with a considerable portion of irony.

Another Dutch literary review, De vrije bladen (The Free Pages, 1924-1931) wanted to be in tune with the time as well (and in this respect wished to be "modern"), yet distanced itself gradually from "the modern," in the sense of avant-gardism and expressionism. In particular, the expansive ethical expressionism represented by the Flemish Wies Moens in the ethically humanitarian magazine De stem (The Voice) and the Catholic review Roeping (Calling) met with opposition from the competing "moderns" of De vrije bladen, who criticized the epigone and superficial imitation of "modern" - metropolitan - imagery and the expansive free verse. In De vrije bladen, the critique of "modernism" (meaning avant-gardism and expressionism), had an obvious strategic element: one had to distance oneself from previous, apparently shallow modernisms, to demonstrate how much one was still up to date.

The poet and critic Marsman, to some extent regarded as the spokesman of his generation, had been involved quite seriously in expressionism (in 1923 his prose still evoked the atmosphere of Kurt Pinthus's Menschheitsdämmerung), but distanced himself more than once from avant-garde 
and expressionist "modernism". Categorically, Marsman declared himself an opponent of "all epigonism and all modernisme-a-tort-et-a-travers" (Goedegebuure [1981], 147). ${ }^{9}$ Almost simultaneously, in a letter to the editor of the Flemish avant-garde review Het Overzicht, Jozef Peeters, Marsman wrote that he had "radically reconsidered all modernism" (De Vree, [1977], 767). ${ }^{10}$ Other contributors took a similar stand, as, for example, the poet and essayist Herman van den Bergh, who had made his debut with a collection of expressionist verse in 1917, but rejected "modernism" in the 1920s. "How many snobs dabble under the eighty-seven banners of modernism," Van den Bergh ([1924], 138) complained in De vrije bladen ${ }^{11}$, notwithstanding his own ambition to be decisively modern himself.

The modern, het moderne (in a positive sense), is associated with intellectual self-constraint and critical distance not only by Van den Bergh, but also by Marsman and other contributors to De vrije bladen - in opposition to "modernism," yet to some extent compatible with the previously described third concept of modernism in current Dutch literary historiography. Not only the decorative and atmospheric sensitivity of the fin de siècle, but also the noisy and apparently formless experiments of expressionism and the avant-garde are rejected as schijnmodernisme - sham modernism. It was in line with this stand that Constant van Wessem ([1925], 264) with considerable relief welcomed the restoration of punctuation in modern literature by Cocteau. There were, in other words, two forms of "the modern," as the poet J. F. Otten argued in 1927, including the "true" modern, which needed no specific form, but emanates from an - intellectualistic, doubting — vision on life. Although "the modern" may have certain forms of its own, avant-garde experiments are expressly excluded by Otten, as manifestations of the "false" modern. "The all too often aprioristic usage of 'modern forms' leads to impurity (Joyce didn't escape this risk in his 'Ulysses'). Modernity turned into modernism," Otten ([1927], 122) stated in De vrije bladen. ${ }^{12}$ Already in 1930, the poet and critic D.A.M. Binnendijk referred to this false form of "the modern" while criticizing another writer for his would-be-modernist work and noted, "[t]hat this modernity manifests itself in a boisterous, hence 'modernist' way" (Binnendijk [1930]: 176). ${ }^{13}$

Also in later years, the term modernism is mainly used to (dis-)qualify expressionist and (other) avant-garde developments. For example, in 1937 in the review Groot Nederland, Simon Vestdijk discussed a Flemish poet, who, "publishing for a decade, remained faithful to "modernism" " (Vestdijk [1937a]: 204). ${ }^{14}$ In the work of another poet, Vestdijk rejected "modernist keys": "jazz," "venal girls," "Lucia Florio who rhymes with radio, Malaga which rhymes with baccarat, La Bohème which rhymes with nothing, not even with "voice' [stem]." His conclusion leaves no room for doubt about his view of "modernism": "This volume is worthless altogether." (Vestdijk [1937b], 410). ${ }^{15}$

At the same time, du Perron made some notes for a never completed article entitled "Herinneringen aan 'modern' Vlaanderen" - memories of 'modern' Flanders, in which he discussed his contacts with the avant-garde artists and writers Jozef Peeters and Michel Seuphor in the early 1920s. The quotation marks around "modern" already indicate Du Perron's later reticence, also obvious from ironical remarks such as: "Poetry by Seuphor, in which a number of the review was equated with a ship. Great! impossible to escape from 'modernism'. I jotted down a few verses" (Du Perron [1959]: 501). ${ }^{16}$

Several of these verses were published by Du Perron in the early twenties under a pseudonym, Duco Perkens. When he met Paul van Ostaijen in the mid-1920s, Du Perron soon distanced himself 
from this modernism. His alias Duco Perkens passed away in 1925. Du Perron himself remained suspicious of "modernism" until his death in 1940, for example in discussions with the co-editor of Forum, the essayist Menno ter Braak.

In 1940, Ter Braak reflected on the terms "modern" and "modernism" in two essays, published in his Verzameld werk (Collected Works) under the titles "De moderne dichter" (The Modern Poet) and "Nogmaals: modern" (Again: modern). In these articles, he made a sharp distinction between the mode-moderne, the fashion(able)-modern, in particular expressionism, on the one hand and a less showy, less superficial modern, represented by authors who "announce a shift in the thinking and feeling of mankind" on the other (Ter Braak [1980]: 476). ${ }^{17}$ Ter Braak continued, as he replaced the qualification mode-moderne by the term modernisme in opposition to the real, authentic modern:

modernism, then, is something which in the way of a fashionable current ages irrevocably, the modern, instead, will still exist, even when the great fashion has faded away and a later generation will only acknowledge the past quality. In this sense, Wies Moens, for example, was modernist, the poet Slauerhoff modern. $\quad(\text { Ter Braak [1980]: 477) })^{18}$

The negative connotation of "modernism" in the Dutch literary field in the early twentieth century can be explained by the fact that the term modernisme was already in use in another context: it was for a long time the common denomination (and condemnation) for "modern" religious-theological developments (more specifically in Flanders, cf. Gobbers [1997]). It is significant that even in the 1970s, Dutch encyclopedias explain "modernism" without exception only as a theological term, pointing either at a (local) development in protestant Calvinist theology, which tried to adapt the Calvinist faith to modern times around the previous turn of the century, or - to some extent comparable - to a Catholic "heresy," explicitly condemned and attacked by the hierarchy of the church (see for example van Deinse et al. [1971], 2:1125).

Although the (double) theological understanding may have prevailed as the common meaning of modernisme in Dutch and Flemish society as a whole, this theological "modernism" only occasionally interfered with the invective "modernism" in the literary field. An early case are the essays by the Catholic Flemish nationalist theatre critic Constant Godelaine, who in several publications - benevolently — criticized "modernism" in the Catholic Flamingant theatre praxis; "modernism" not only (on an aesthetic level) as a label for expressionist and avant-garde tendencies, but also (on a theological level) as label for a more modern interpretation of Catholic morality (for example Godelaine [1926] and [1940]).

A more recent case is offered by the interventions of the Frisian senator Hendrik Algra, editor-inchief of the conservative Calvinist daily Friesch Dagblad and representative of the no less conservative Calvinist Anti-Revolutionaire Partij (Anti-Revolutionary Party, ARP) in the Eerste Kamer, the Dutch Senate. In the early sixties, Algra frequently fulminated against "modernist" developments in Dutch culture and presented mid-nineteenth-century Dutch literature dominated by Calvinist clergymen as well as classical seventeenth-century religious literature as the real pious alternative for modernist aberrations (cf. Ouboter [1966], Fekkes [1968]). In a debate in the Eerste Kamer on state subsidies for Dutch writers on May 14, 1963, Algra firmly opposed these subsidies for "modernists" like Remco Campert, Lucebert, Simon Vinkenoog and Gerard van het Reve. From his perspective, 
a bunch of writers, [...] a 'group', group in the same sense as some biking groups, with a common meeting point, a 'group' in which there is no place for the altar, only for a drinking table, where rowdies are welcomed and pilgrims jeered off. (Verslag [1963], 2256) ${ }^{19}$

The subsequent reaction by the Labour senator Cammelbeeck in the same debate is remarkable. Cammelbeeck was a proponent of state subsidies for "modern" writers and "the avant-garde" (this is contemporary, post-war experimental writers), yet, in his response to Algra, he too rejected "modernism" - in line with the earlier critique of modernism by Ter Braak:

When modern writers are modernists, I'll immediately keep well clear of modern writers, but I will also keep clear of seventeenth-century modernists. I am only interested in authentic authorship [...] (Verslag [1963], 2282) $)^{20}$

\section{Modernism as a Category in Twentieth-Century Dutch Literary Historiography}

The contemporary usage of the term "modernism" in the historiography of Dutch literature is based only to a small extent on local tradition, as the quite different implementation of the term "modernism" in the Dutch literary field in the first half of the twentieth century and beyond indicates. To some extent, modernisme may have served already as an umbrella term for the innovative practice of the historical avant-garde in the early twentieth century, yet generally with a negative connotation, as, for example, in a schoolbook history of Dutch literature from 1932, Stroomingen en hoofdpersonen in de Nederlandsche literatuur (Movements and Figures in Dutch Literature), in which "modernism" is used as a negative qualification for literary avant-gardism in the 1910s and 1920s (Meijer Drees [1932], 196).

"Modernism" still kept its predominantly negative connotation in Dutch in the years after World War II, as the remarks of Algra and Cammelbeeck in the Dutch senate indicate. Little by little, though, a shift can be observed in this period, to some extent influenced by international developments in the cultural field, but probably also as a result of the decreasing role of the church in Dutch society. As early as 1950, the seventh edition of the major Dutch dictionary, Van Dale's nieuw groot woordenboek der Nederlandse taal (Van Dale's New Dutch Dictionary), mentioned next to the theological use of the term "modernism" another, wider understanding of "modernism" in the more or less neutral sense of "the spirit of the new in society, literature, and art" (Kruyskamp and De Tollenaere [1950], 1101). ${ }^{21}$ In the course of time, "modernism" became gradually a neutral classification. It is noteworthy here that the term was already used in such a neutral way in the early sixties by the Dutch Central Bureau for Statistics for "the group of young, post-war writers who should be distinguished clearly from the pre-war generation of writers," among others Campert, Lucebert, and Vinkenoog (Verslag [1963], 2255). ${ }^{22}$ Occasionally, this new generation of innovative writers in the 1950s and 1960s, who experimented in the tradition of the historical avant-garde, also referred to themselves as "modernists" or were labeled as such by charitable critics (cf. Buckinx [1953], Thomas [1961], Anonymus [1965], Weisgerber [1970]). Likewise, "modernist themes" were also discerned in a similar neutral way in a popular Dutch literary history for schools in the same period (de Vooys and Stuiveling [1965], 169).

Little by little, "Modernism" may have lost its invective character in the first decades after the war; it was, however, still far from being a prominent term in the Dutch or Flemish literary field, as 
may be indicated by the fact that the first edition of the Moderne Encyclopedie van de Werelditeratuur (Modern Encyclopedia of World Literature) in 1968, written and edited by a wide range of Dutch and Flemish literary scholars, had no separate entry for the term. Only in the second edition of 1982 was an entry on a little French review from 1889 entitled Le Moderniste replaced by one on modernisme.

Three developments in the intermediate period (and following years) seem to be essential for the separate entry of modernisme in this encyclopedia. In the first place, the foreign, international orientation of the Dutch literary field changed. Initially, in the first half of the twentieth century, the Dutch literary field focused in particular on France and Germany, or rather: on Paris and Berlin. After World War II and the trauma of the German occupation, the relevance of the German orientation rapidly diminished. The role of France (Paris) decreased as well in later years due to the growing importance of the United States as the Western superpower in cultural matters as well as in economic and military fields. As a consequence, the significance of English literature and the relevance of an English-American orientation increased. It is probably no coincidence that the introduction of the term modernisme as a more systematic, prominent term in Dutch literary history, did not occur in the Low Countries, but in England and in the United States: In 1973 a symposium of mostly Dutch scholars on "Modernism in the Low Countries, 1915-1930" took place at the University of Texas in Austin (cf. Bulhof [1976]). In 1976 A.L. Sötemann presented the case of the moderate modernist Nijhoff to the Modern Languages Society in Cambridge (cf. Sötemann [1977] and [1978]).

Sötemann's lecture and the Austin symposium point also to further developments in the Dutch literary field and, more in particular, in Dutch literary studies. Due to the increasing internationalization of culture and academia, there is a growing urge to describe and present Dutch literature in an international context. As part of this development, local particularities are downplayed in favor of phenomena that can be found in other literatures as well, especially in English and American literature. Likewise, local divisions in periods, currents and groups are replaced by international, or to be more precise, English and American classifications, as in the case of the Forum group nowadays being subsumed under the caption "modernism". In this sense, modernism has become a term that allows more recent studies on modernisme in early twentieth-century Dutch literature to present the work of writers like Nijhoff, Ter Braak, Du Perron, or Vestdijk as — national — Dutch contributions to an - international - modernism.

Last but not least, the emergence of modernism as a prominent term in Dutch literary studies is unthinkable without the introduction of another term: postmodernism. It was, actually, the introduction of the soon very popular notion of "post-modern" in Dutch literary criticism in the 1980s as general caption for contemporary developments in literature, art, and society, which brought the final breakthrough of "modernism" in Dutch literary history. Until the 1980s, the term (and concept of) modernism was a marginal phenomenon in Dutch literary studies. A brief look at the indexes of the main bibliography of Dutch literary studies (Bibliografie van de Nederlandse taal- en letterkunde [BNTL], Bibliography of Dutch Linguistics and Literature) manifests no significant presence of the term until the 1980s, most certainly not as a major term. "Modernism" is even completely absent in the volumes covering 1965 to 1974, as Francis Bulhof already noted (Bulhof [1995], 237). After the mid-1980s, however, a considerable rise in publications on modernism in Dutch literature can be observed in the BNTL. In part, this may be seen as a result of the impact of Fokkema's and Ibsch's 
Modernism in European Literature, which gained considerable attention after its first publication in 1984 (cf. Bulhof [1995], 242) — not least due to their effort to present a number of prominent Dutch authors, like Ter Braak, Du Perron, Van Bruggen, and Vestdijk, who were until then, in a Dutch setting, mainly discussed as authors in their own right (and not so much as representatives of some ism) in an international framework next to big names such as James Joyce, Marcel Proust, and Thomas Mann. Similarly important, however, is the arrival of the notion "postmodernism" in the Low Countries in the same years, at a stage when "modernism" is still virtually absent in Dutch critical discourse (cf. e.g. Hudson and Van Reijen [1986], Goedegebuure [2001], Groen [1988], Vuyk [1999]). As Ulrich Weisstein ([1995], 414) has argued, postmodernism is unthinkable without its "antecedent," modernism. Also in the context of Dutch literary criticism and studies, the emergence of a contemporary "postmodernism" necessitated the introduction of a hitherto missing "modernism" in Dutch literature. Weisstein argues in more general terms that "modernism" can also serve as "a natural Lückenbüsser" between the experimental stage of modern art in the historical avantgarde of the 1910s and 1920s and its neo-avant-garde resurgence in the 1950s and 1960s (Weisstein [1995], 413). "Modernism" seems indeed to fulfill this double function, facilitated by the fact that "modernism" can serve as a hitherto missing umbrella term for developments in Dutch literature of the 1930s (previously and by some still discussed not as "modernism," but simply as "the thirties").

The fact that "modernism" is now used frequently in Dutch literary historiography may not be only the result of the English-American orientation of the literary field, the growing internationalization of Dutch literary studies, and the necessity of a modernism preceding postmodernism, but also of the fact that in the meantime - at the end of the twentieth century - a considerable historical distance has grown between contemporary literature and developments in the Dutch literary field before World War II. In part, this distance may draw attention to constellations that are obvious in retrospect, but that were still invisible to writers and critics in the literary field half a century earlier. At the same time, it should not be ignored that "modernism" in Dutch literature is primarily an historiographical phenomenon, and only as such an historical phenomenon as well. This modernism may offer the possibility, on the one hand, of discerning and constructing new (or old) historical relations and constellations. On the other hand, this same modernism tends to distract attention from real and superficial historical controversies and polemics in the Dutch literary field between the two world wars, as for example the clear-cut enmity between Martinus Nijhoff and the Forum editors Ter Braak en Du Perron, who nowadays figure together as modest, detached, cautiously rational, self-reflective, intellectualist protagonists of Dutch modernism, whereas in the 1930s Du Perron and Nijhoff were involved in occasional brawls on the doorsteps of the Amsterdam Hotel Américain. As Du Perron related in a letter to Menno ter Braak about this fight with "Pom," as Nijhoff was nicknamed:

Pom was a bit tight; Stols started to stir things up; Pom behaved quite quarrelsomely and talked about 'trashing the matter out outside' and so on, until I let him have it his way. The fight was brief and foolish, and curdled in the arms of many taxi drivers. Pom scratched me under my nose, and I gave him two clouts, one of which was, by his own account, 'damned good' and right on the middle of his nose. I considered it a ridiculous event from beginning to end and was not really angry myself; but I did not want to grant him the legend that he had to call me outside three times in vain, or something like that [...]. (Ter Braak and Du Perron [1962], 155). ${ }^{23}$

(C) 2007. John Benjamins Publishing Company

All rights reserved 
We may welcome the fact that "modernism" conciliated both parties over time, but it is unfortunate that such very real literary-historical conflicts have been simultaneously glossed over by this same term.

\title{
Notes
}

1. "Maar rond de Eerste Wereldoorlog begint een nieuwe grote cultuurhistorische periode, die we het modernisme noemen en waarin we nog steeds leven. Alles wat wij nu 'moderne kunst' noemen, is ontstaan in het eerste kwart van de 20e eeuw. De kunstenaars van nu werken vanuit dezelfde principes als die van rond 1915."

2. "Wie enigszins met de Nederlandse literatuur vertrouwd is, zal zich verbazen over het ontbreken daarvan bij Bradbury [en McFarlane]."

3. "Met geen woord wordt gesproken over Van nu en straks, het tijdschrift dat in België het moderne levensgevoel vertegenwoordigde."

4. "Van deze meest radicale modernistische revolutie in de Europese literatuur van het fin de siècle wordt bij Bradbury [en McFarlane] met geen woord gerept. De kans op integratie van de Nederlandse literatuur in het grotere Europese verband is daardoor eens te meer onbenut gebleven. Op deze eerste modernistische golf is rondom de Eerste Wereldoorlog een tweede gevolgd, waarin avant-garde-bewegingen zoals imagisme, futurisme, expressionisme, dadaïsme en surrealisme de boventoon voerden. Maar ook daar is de Nederlandse inbreng in het internationale literatuurwetenschappelijke debat minimaal, terwijl het allerminst heeft ontbroken aan Nederlandse en Belgische bijdragen aan de literatuur zelf."

5. "èn in de organies-expressionistiese dichtkunst èn in de organies-expressionitiese schilderkunst [wordt gestreefd] naar een formele aseïteit, maar een konstruktie uit het afwegen tegenover elkaar van in zichzelf reeds gave gedeelten [...].' [...] Organies-expressionistiese atmosfeer is ten slotte dit trillen dat ligt tussen twee geïsoleerde groepen [van lichamen of woorden]. [...] Vóór ik het woord zeg is er een haken naar het uitdrukken van het onbekende [...]. Telkens wordt de uitdrukking gewijzigd door haar eigen verrassingen. [...] Het schilderij wordt op het doek, het worden van een gedicht bepaalt mede zijn inhoud."

6. "ZEER KLEINE SPEELDOOS

\author{
Amarillis \\ hier is \\ in een zeepbel \\ Iris \\ hang de bel \\ aan een ring \\ en de ring \\ aan je neus \\ Amarillis \\ Schud je 't hoofd \\ speelt het licht \\ in de bel \\ met Iris \\ Schud je fel \\ breekt de bel \\ Amarillis
}

(C) 2007. John Benjamins Publishing Company

All rights reserved 


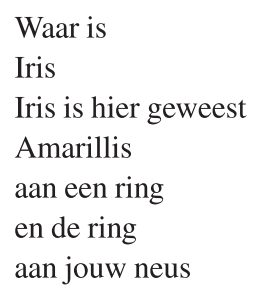

Wijsneus

Amarillis"

7. "BOHEMIENGEIST (FREIHEITSSINN), MODERNISMUS, INTERNATIONALISMUS, URPROVI[N]ZIALISMUS war die Basis unseres Denkens..." (Dijkstra [1927], 3).

8. "dilettantismo e [...] snobismo modernista."

9. "tegen alle epigonisme en alle modernisme-a-tort-et-a-travers".

10. "radicaal van elk modernisme [te zijn] teruggekomen".

11. "Hoeveel snobs er onder de zevenentachtig vanen van het modernisme liefhebberen."

12. "Het al te vaak aprioristisch gebruiken der 'moderne vormen' leidt tot onzuiverheid (Joyce ontkwam in zijn 'Ulysses' niet aan dit gevaar). Moderniteit werd modernisme."

13. "Dat deze moderniteit zich nog wel eens te luidruchtig, en dus 'modernistisch', manifesteert."

14. Reeds een tiental jaren publiceerend, is hij het 'modernisme' trouw gebleven."

15. "modernistische toetsen" ... "jazz" ... "veile meisjes" ... "Lucia Florio die op radio rijmt, Malaga dat op baccarat rijmt, La Bohème dat nergens op rijmt, zelfs niet op 'stem'." ... "Als geheel is deze bundel waardeloos."

16. "Poëzie van Seuphor, waarin een nr. van het blad met een schip werd gelijkgesteld. Enorm! er viel niet te ontkomen aan het 'modernisme'. Ik schreef haastig een paar verzen."

17. "... een verschuiving aankondigen in het denken en voelen der mensen."

18. "het modernisme is dan iets, dat als modestroming onherroepelijk veroudert, het moderne daarentegen bestaat ook nog, als de grote mode is weggeëbd en een latere generatie in het verleden alleen nog de qualiteit erkent. In die zin was b.v. Wies Moens modernistisch, de dichter Slauerhoff modern."

19. "een schrijversbent [...], een 'groep', groep in dezelfde zin als sommige nozemgroepen, die ook een gemeenschappelijk trefpunt hebben, een 'groep', in wier milieu geen plaats is voor een altaar, maar wel voor een bittertafel, waar men de nozems verwelkomt en de pelgrims achterna schreeuwt."

20. "Als moderne schrijvers modernisten zijn, moet ik reeds van moderne schrijvers niets hebben, maar ik moet ook niets hebben van modernisten uit de zeventiende eeuw. Het gaat mij werkelijk om authentiek schrijverschap."

21. "... de geest van het nieuwe in maatschappij, letteren en kunst."

22. ".... de groep jonge na-oorlogse auteurs, die duidelijk te onderscheiden is van de vooroorlogse schrijversgeneratie."

23. "Pom was aangeschoten, Stols begon te stoken, Pom deed erg haantjesachtig, sprak van 'buiten uitknokken' en zoo meer, tot ik hem zijn zin gegeven heb. De strijd was kort en idioot en stolde in de armen van vele taxichauffeurs. Pom heeft me onder mijn neus gekrabd, en ik heb hem twee muilperen verkocht, waarvan één, volgens zijn eigen zeggen, 'verdomd goed' en precies midden op zijn neus. Ik vond het een belachelijke historie van begin tot eind en heb me geen oogenblik boos kunnen maken; maar ik wou hem de legende niet gunnen van mij 3 x tevergeefs naar buiten te hebben geroepen of zoo."

(C) 2007. John Benjamins Publishing Company

All rights reserved 


\section{Bibliography}

van der Aa, Manu. 1994. E. du Perron en de avant-garde: kroniek van een heilzame ziekte. Amsterdam: Lubberhuizen.

Aerts, José, A. G. H. Bachrach et al., eds. 1968. Moderne encyclopedie der wereldliteratuur. Vol. IV. Hilversum: Brand, De Haan.

van den Akker, Wiljan. 1994. Dichter in het grensgebied. Over de poëzie van M. Nijhoff in de jaren dertig. Amsterdam: Bert Bakker.

- 1996. Martinus Nijhoff, a Dutch master of modernism. The Low Countries. Arts and Society in Flanders and the Netherlands. 3:213-19.

van den Akker, Wiljan, and Gillis Dorleijn. 2000. Hoe lang duurt Tachtig? Reproductie van normen en literatuurgeschiedschrijving. Literatuurwetenschap tussen betrokkenheid en distantie. Ed. by Liesbeth Korthals Altes and Dick Schram. Assen: Van Gorcum. 1-14.

Anbeek, Ton. 1987. Normverandering: een test-case '1916' in de Nederlandse literatuur. Spektator. 17.1:3-16. Anonymous. 1925. Tijdschriften. Revues modernistes. Het Overzicht. 5.22-4, n.p. [back cover].

Bachrach, A. G. H., et al., eds. 1982. Moderne encyclopedie van de wereldliteratuur. Vol. VI. Haarlem, Antwerp: De Haan, De Standaard.

Beekman, Klaus. 1985. De duurzaamheid van de avantgarde. Literatuur. 2.4: 205-12.

van den Berg, Hubert F., and Gillis J. Dorleijn, eds. 2002. Avantgarde! Voorhoede? Vernieuwingsbewegingen in Noord en Zuid opnieuw beschouwd. Nijmegen: Vantilt.

van den Bergh, Herman. 1924. Over Guilaume Apollinaire. III. De Vrije Bladen. 1:131-46.

Binnendijk, D. A. M. 1930. Twee debutanten. De Vrije Bladen. 7: 172-9.

Bloemlezing van modernismen (en archaïsmen) door een dilettant. 1921a. Het Getij. 6.2: 86-7.

Bloemlezing van modernismen (en archaïsmen) door een dilettant. 1921b. Het Getij. 6.2: 135-6.

Blotkamp, Carel. 1989. Willink, Du Perron en het modernisme. Nadruk. 1.4:3-12.

den Boef, August Hans. 1991. Musil? Ken ik niet: Ter Braak en Du Perron over modernisten en epigonen. Leiden: Dimensie.

van den Boogaard, Oscar. 1999. Liefdesdood. Amsterdam: Querido.

van Bork, G. J., and N. Laan, eds. 1986. Twee eeuwen literatuurgeschiedenis: poëticale opvattingen in de Nederlandse literatuur. Groningen: Wolters-Noordhoff.

ter Braak, Menno. 1980. Menno ter Braak. Verzameld werk. Vol. VII. Amsterdam: G.A. van Oorschot: 478-88. ter Braak, Menno, and E. du Perron. 1962. Briefwisseling 1930-1940. I. Amsterdam: G.A. van Oorschot.

Bradbury, Malcolm, and James McFarlane. 1991. Modernism. A Guide to European Literature 1890-1930. Harmondsworth: Penguin.

Brandt Corstius, Jan. 1976. The International Context of Dutch Literary Modernism 1915-1930. Nijhoff, Van Ostaijen, "De Stijl". Modernism in the Netherlands and Belgium in the First Quarter of the 20th Century. Ed. by Francis Bulhof. The Hague: Martinus Nijhoff. 8-19.

Bronzwaer, W. 1988. T. S. Eliot en Igor Stravinsky. Twee meesters van het modernisme. T. S. Eliot. Een Amerikaan in Europa. Ed. by W. Bronzwaer et al. Baarn: Ambo. 88-110.

- 1991. Een verstrooid zelfportret: Nijhoffs 'De Wandelaar' en het modernisme. Het eerste spoor. Opstellen over literatuur en moderniteit. Baarn: Ambo. 106-19.

Bruinsma, Ernst. 1998. Louis Paul Boon en het modernisme in Vlaanderen. Antwerpen: L. P. Boon-Documentatiecentrum, Universiteit Antwerpen.

Buckinx, Pieter G. 1953. Vlaamse modernistische poëzie. Critisch bulletin. 20.10:459-63.

(C) 2007. John Benjamins Publishing Company

All rights reserved 
Buelens, Geert. 1996. Wat is dan uwe hoop die gij nauwelijks durft zeggen: oorlog, nihilisme en modernisme in 'Bezette Stad'. De stem der Loreley: over Paul van Ostaijen. Ed. by Geert Buelens and Erik Spinoy. Amsterdam: Bert Bakker. 129-46.

Buelens, Geert. 1997. Paul van Ostaijen: avant-garde modernist? Handelingen van de Koninklijke Zuid-Nederlandse Maatschappij voor Taal- en Letterkunde en Geschiedenis. 51:23-40.

- 2000. De suggestie van het oosten. Modernistische poëzie in het spoor van de Chinese klassieken. Literatuur. 17.2: $90-5$.

Bulhof, Francis. 1995. Contrast en realiteit: het debat over het modernisme in de Nederlandse literatuurwetenschap. Forum der Letteren. 36.3:236-46.

- ed. 1976. Nijhoff, Van Ostaijen, "De Stijl". Modernism in the Netherlands and Belgium in the First Quarter of the 20th Century. The Hague: Martinus Nijhoff.

Bürger, Peter. 1974. Theorie der Avantgarde. Frankfurt am Main: Suhrkamp.

Calinescu, Matei. 1987. Five Faces of Modernity: Modernism, Avant-garde, Decadence, Kitsch, Postmodernism. Durham: Duke University.

Chamuleau, R. B.F.M., and J.A. Dautzenberg. 1991. Overzicht van de Nederlandse letterkunde van de 19 e en 20e eeuw. Nederlandse letterkunde. Vol II. Utrecht: Het Spectrum.

Dautzenberg, J. A. 1989. Nederlandse literatuur. Geschiedenis, bloemlezing en theorie. Den Bosch: Malmberg.

van Deinse, A. M. J. 1971. Kleine Winkler Prins. 3 vols. Amsterdam, Brussel: Elsevier.

Denoo, Joris. 1978. 'Mijn modernisme tast het modernisme aan', of Polets eenzame statuut in de letteren. Dimensie. 2.6:37-9.

Dijkstra, Johan. 1927. De Ploeg. Groningen Holland 1927. Groningen: H. N. Werkman.

van Doesburg, Theo. 1920. L'arte nuova in Olanda (Parte III). Valori Plastici. 2.1-2:20.

- 1921. Revue der Avant-garde. Het Getij. 6.1:109-12.

Drijkoningen, Ferdinand. 1982. Inleiding. Historische Avantgarde. Programmatische teksten van het Italiaans futurisme, het Russisch futurisme, dada, het constructivisme, het surrealisme, het Tsjechisch poëtisme. Ed. by Ferdinand Drijkoningen and Jan Fontijn. Amsterdam: Huis aan de drie grachten. 11-51.

Fekkes, Jan. 1968. De God van je tante ofwel het Ezel-proces van Gerard Kornelis van het Reve. Amsterdam: De Arbeiderspers.

Fokkema, Douwe. 1986. Modernisme. Modernen versus postmodernen. Ed. by Wayne Hudson and Willem van Reijen. Utrecht: HES. 113-33.

Fokkema, Douwe, and Elrud Ibsch. 1984. Het modernisme in de Europese Letterkunde. Amsterdam: Arbeiderspers.

1987. Modernist Conjectures in European Literature 1910-1940. London: Hurst.

Fontijn, Jan, and Inge Polak. 1986. Modernisme. Twee eeuwen literatuurgeschiedenis: poëticale opvattingen in de Nederlandse literatuur. Ed. by G.J. van Bork, N. Laan. Groningen: Wolters-Noordhoff. 182-207, $225-9$.

Friedrich, Hugo. 1956. Die Struktur der modernen Lyrik. Von der Mitte des neunzehnten bis zur Mitte des zwanzigsten Jahrhunderts. Reinbek: Rowohlt.

Gaston Burssens in memoriam. 1965. Tijdingen uitgegeven door het modernistisch kunstcentrum Kunst en Poёzie. 1.4:2.

Gillet, Louis. 1988. Anti-modernistische strekkingen 1921-1948. Van "Arm Vlaanderen" tot "De voorstad groeit": de opbloei van de Vlaamse literatuur van Teirlinck-Stijns tot L. P. Boon, (1888-1946). Ed. by M. Rutten and Jean Weisgerber. Antwerpen: Standaard. 395-405.

Gobbers, Walter. 1997. 'Modernisme' en 'avant-garde' als poëticale concepten, resp. literair-historische categorieën in en m.b.t. de Vlaamse fin de siècle- en avant-gardeliteratuur van De Mont tot Van Ostaijen. Het talig wezen: opstellen aangeboden aan professor dr. Louis Gillet ter gelegenheid van zijn afscheid als hoogleraar aan de Université de Liège. Ed. by Fr. van Elmbt and Ph. Hiligsmann. Liège: Université de Liège. 53-68.

(C) 2007. John Benjamins Publishing Company

All rights reserved 
Godelaine, Constant. 1926. Modern en Modernistisch Tooneel in Nederland. Katholieke Vlaamsche Hoogeschooluitbreiding. 23.1: 1-46.

- 1940. Dr Osc. de Gruyter. De flamingant en de tooneelman in het licht van het modernisme. Tongeren: Michiels-Broeders.

Goedegebuure, Jaap. 1981. Op zoek naar een bezield verband. De literaire en maatschappelijke opvattingen van H. Marsman in de context van zijn tijd. 2 vols. Amsterdam: G.A. van Oorschot.

—. 2001. Postmoderne modernisten en modernistische postmodernen: Nederlandstalige schrijvers van de twintigste eeuw herlezen. Nederlandse Letterkunde. 6.1:13-32.

Groen, Hein. 1988. De postmodernistische grensoverschrijding van de modernistische wereldbeschouwing. Forum der letteren. 29.1:42-51.

Grüttemeier, Ralf. 1995. Twist met ons, twist met ons, twist niet met mate. Literatuur. 12.2: 112-13.

Hadermann, Paul. 1988. De modernistische doorbraak. Van "Arm Vlaanderen" tot "De voorstad groeit": de opbloei van de Vlaamse literatuur van Teirlinck-Stijns tot L. P. Boon, (1888-1946). Ed. by M. Rutten and Jean Weisgerber. Antwerpen: Standaard. 271-364.

- 1993. 1 april 1925: het eerste nummer van De driehoek verschijnt: een modernistisch driemanschap: Van Ostaijen, Burssens, Du Perron. Nederlandse literatuur, een geschiedenis. Ed. by M. A. Schenkeveld-van der Dussen. Groningen: Nijhoff. 621-9.

Hudson, Wayne, and Willem van Reijen, eds. Modernen versus postmodernen. Utrecht: HES.

Ibsch, Elrud. 1991. Algemene inleiding: wat noemen wij modernisme? Modernisme in de literatuur: James Joyce, Italo Svevo, Marcel Proust, Martinus Nijhoff. Ed. by J. B. Weenink. Amsterdam: VU Uitgeverij. $1-28$.

de Jong, Martien J.G. 1979. De verlossing van Venus en andere essays. The Hague, Rotterdam: Nijgh \& van Ditmar.

1982a. Romantisch modernisme en wijsneuzige kritiek. Nieuw Vlaams tijdschrift. 35.5: 774-90.

1982b. Marsmans "Seinen" tussen Duits en Frans modernisme. Ons erfdeel. 25.5: 686-95.

Kruyskamp, C., and F. de Tollenaere, eds. 1950. Van Dales nieuw groot woordenboek der Nederlandse taal. Seventh edition. The Hague: Martinus Nijhoff.

Levie, Sophie. 1988. Commerce, 1924-1932. Een internationaal modernistisch tijdschrift. Nijmegen: SSN.

- 1991. Literatuurgeschiedschrijving. Literatuur en context: een inleiding in de literatuurwetenschap. Ed. by Peter Zeeman. Nijmegen: SUN. 252-79.

Mandelinck, Gwij. 1991. Dakloos, tussen traditie en modernisme. 'Opener dan dicht is toe'. Ed. by Hugo Brems and Dirk de Geest. Leuven: Acco. 242-3.

Meijer Drees, N. C. 1932. Stroomingen en hoofdpersonen in de Nederlandsche literatuur. Groningen, Batavia: Noordhoff.

van Montelbaan, Reinout. 1996. De literatuur op de terugtocht (van modernisme naar academisme). Appel. 21.4: $260-4$.

Musschoot, Anne Marie. 1979. Het modernisme van Van Ostaijen in het licht van de literatuurwetenschap. Bzzlletin. 7.66: 153-9.

Nicholls, Peter. 1995. Modernisms. A Literary Guide. Houndmills, London: MacMillan.

van Ostaijen, Paul. 1979a. Verzameld werk. Poëzie. Bezette Stad. Nagelaten gedichten. Amsterdam: Bert Bakker.

1979b. Verzameld werk. Proza. Besprekingen en beschouwingen. Amsterdam: Bert Bakker.

Otten, J. F. 1927. Modern. De Vrije Bladen. 4:119-22.

Ouboter, Cornelis. 1963. Modernisten in het geding. Ontmoeting. 16.8-9:225-32.

- 1966. Moderne literatuur-confrontatie met een notie. Wending. 21.4-5:308-22.

Oversteegen, Jacob Jan. 1967. Vorm of vent. Opvattingen over de aard van het literaire werk in de Nederlandse kritiek tussen de twee wereldoorlogen. Amsterdam: Athenaeum-Polak \& van Gennep.

(C) 2007. John Benjamins Publishing Company

All rights reserved 
du Perron, E. 1959. Herinneringen aan 'modern' Vlaanderen. Verzameld werk. Vol. VII. Ed. by E. du Perronde Roos, F.E. A. Batten and H. A. Gomperts. Amsterdam: G.A. van Oorschot. 500-2.

van der Ploeg, Kees. 2000. 'De Ploeg' und der Modernismus. Avantgarde in het Noorden/Noordwesten = Avantgarde im Norden/Nordwesten. Ed. by Hubert van den Berg and Ralf Grüttemeier. Groningen: Universiteitsbibliotheek. 91-101.

Quinones, Ricardo J. 1985. Mapping Literary Modernism. Time and Development. Princeton: Princeton University Press.

Riding, Laura, and Robert Graves. 1927. A Survey of Modernist Poetry. London: Heinemann.

Ruiter, Frans, and Wilbert Smulders. 1996. Literatuur en moderniteit in Nederland 1840-1990. Amsterdam: De Arbeiderspers.

Sanders, Andrew. 1996. The Short Oxford History of English Literature. Oxford: Clarendon.

Sötemann, August Lammert. 1976. "Non-spectacular" Modernism: Martinus Nijhoff's Poetry in its European Context. Nijhoff, Van Ostaijen, "De Stijl". Modernism in the Netherlands and Belgium in the First Quarter of the 20th Century. Ed. by Francis Bulhof. The Hague: Martinus Nijhoff. 95-116.

- 1977. Some suggestions concerning two modernist traditions in European poetry. Dutch Studies. 3:93-111.

1978. Twee modernistische tradities in de Europese poëzie: een paar ideeën. Revisor. 5.4:44-53.

Thomas, Piet. 1961. Regressie en modernisme. Dietsche warande Belfort. 106.8: 577-83.

Tijdschriften - Revues modernistes. 1925. Het Overzicht. 2.22-4: 184.

Vaessens, Thomas. 1998. Circus Dubio \& Schroom: Nijhoff, Van Ostaijen en de mentaliteit van het modernisme. Amsterdam: De Arbeiderspers.

Verslag der handelingen van de Eerste Kamer der Staten-Generaal gedurende het zittingsjaar 1962-1963. Vol. II. The Hague: Staatsdrukkerij.

Vestdijk, S. 1937a. Poëtisch maandbericht. Katholieke dichters. Groot Nederland. 35.1:200-5.

- 1937b. Poëtisch maandbericht. Vlaamsche en Zuid-Afrikaansche poëzie. Groot Nederland. 35.1:40612.

de Vooys, C. G.N., and Garmt Stuiveling. 1965. Schets van de Nederlandse letterkunde. Groningen: Wolters.

de Vree, Paul. 1977. Hendrik Marsman en het modernisme. Nieuw Vlaams tijdschrift. 30.9: 766-76.

Vuyk, Kees. 1999. Hoe niet te spreken over schuld: vier vormen van modernisme in 'Liefdesdood' van Oscar van den Boogaard. Revisor. 26.5: 77-86.

de Waard, Elly. 1999. 'De tijd der eenzijdige bewegingen is voorbij'. Revisor. 26.5:4-25.

Weisgerber, Jean. 1970. Hugo Claus: experiment en traditie. Leiden: Sijthoff.

—. 1989. Avant-garde, modernisme. Brussel: VUB-Press.

- 1991. Les Avant-gardes littéraires en Belgique. Au confluent des arts et des langues (1880-1950). Bruxelles: Labor.

—

Weisstein, Ulrich. 1995. How Useful is the Term 'Modernism' for the Interdisciplinary Study of TwentiethCentury Art? The Turn of the Century. Le tournant du siècle. Modernism and Modernity in Literature and the Arts. Le modernisme et la modernité dans la littérature et les arts. Ed. by Christian Berg, Frank Durieux and Geert Lernout. Berlin, New York: Walter de Gruyter. 409-41.

van Wessem, Constant. 1925. Over Jean Cocteau. De moderne gevoeligheid. De Vrije Bladen. 264-8.

(C) 2007. John Benjamins Publishing Company

All rights reserved 